\title{
INTENTION IN SWITCHING TO ELECTRONIC MONEY IN MILLENNIAL GENERATION
}

\author{
Ricky Angga Ariska ${ }^{1}$ \\ 1) Universitas Wijaya Kusuma Surabaya
}

\begin{abstract}
This research is talk about switching from conventional money to electronic money in millennials generation. Sampling technique used in this research is purposive sampling. Respondent criteria are individual that have electronic money account and have done transactions three times using electronic money. The research sample used was 100 respondents. The analysis technique used in this research is validity test, reliability test, multiple regression model analysis, $\mathrm{F}$ test, and $\mathrm{t}$ test. The results of this study are compatibility and perceived content have a significant effect to intention to switch. Only convenience is has no effect to intention to switch.
\end{abstract}

Keywords : new product attributes; intention to switch; electronic money

Correspondence to : rickyanggaariska@uwks.ac.id

\section{INTRODUCTION}

Technology has evolved over time, from simple technology to sophisticated technology. The rapid development of technology today is in terms of information technology. There are many economic activities that utilize technology. History proves that the development of payment instruments continues to change from the form of coins to banknotes, until now it has evolved in the form of data that can be placed on a container or called an electronic payment instrument (Adiyanti 2015).

Electronic money (e-money) is a a certain amount of money is stored electronically in an electronic device (Bank of International Settlement). Electronic money can be obtained by depositing a sum of cash or by debiting an account at a bank to then feed it into his electronic money device. With that device, the owner can make payments or receive payments, where the value will decrease when used to make payments or increase if receiving payments or upon replenishment.

The biggest e-money user is a millennials. They understand more about technology. Millennials grew up in an age where the internet became a new way of life. One of millenials characteristic is "always on", they always active in social media and internet.

Intention to Switch

Some of the customers do the switching due to customer dissatisfaction with the product that has been purchased, the service is not satisfactory or just because of boredom (Schiffman and Kanuk 2010). Intention to switch is a signal of termination of customer relations with current service 
providers either partially or completely (Jabeen, Hamid, and Rehman 2015). Intention to switch as a level of likelihood or certainty that customers will move from the current service provider to the new service provider (Bansal 2005).

\section{THEORY STUDY}

New Product Attributes

The factors that can influence the intention to switch are as follows:

a. Compatibility, is the extent to which innovation is considered consistent with existing values, past experience, and the needs of potential adopters (Rogers 1995) in (Liander, Margaretha, and Anandya 2016).

b. Complexity, is the extent to which innovation is considered relatively difficult to understand and use (Rogers 1995: 242) in (Liander et al. 2016).

c. Convenience, is the ease in carrying something, using something, accessing even though many sources of information are free and in the process of use (Chiang and Chen 2014) in (Liander et al. 2016).

d. Perceived content, is the user's perception of the quality (usage) and information provided by a website (Lin 2009) in (Liander et al. 2016).

Millenials

Oxford Living Dictionary describes a millennial as a person reaching young adulthood in the early 21st century (oxforddicrionaries.com, Retrieved 23 March 2019). Pew Research Center gave a grouping of generations:

a. The Silent Generation: born 1928-1945 (73-90 years old).

b. Baby Boomers: born 1946-1964 (54-72 years old).

c. Generation X: born 1965-1980 (38-53 years old). d. Millennials: born 1981-1996 (22-37 years old).

e. Post-millennials: born 1997-Present (0-21 years old).

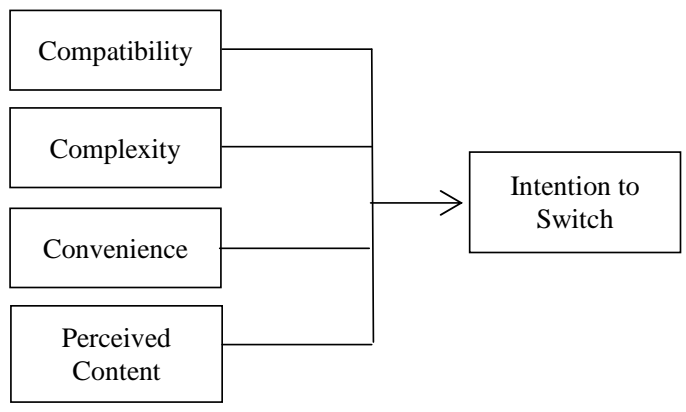

Figure 1. Analysis Model Framework

\section{METHODS}

This research is an associative research using quantitative method. Associative research is research aimed to determine the effect or relationship between two or more variables. The procedure of determining the sample in this study uses a purposive sampling technique. Criteria in determining the sample in this study are millennial 21 to 37 years old who have an e-money account and have transaction using e-money.

The variables used in this study are independent variables consisting of indicators of new product attributes (compatibility, complexity, convenience, and perceived content) and the dependent variable used is intention to switch.

The sample in this study amounted to 80 respondents. Determination of the number of samples is 20 times the number of independent variables (Hair 2010). This study uses 4 independent variables, in this case the minimum number of samples was 80 respondents. The 80 respondents is not a fixed number, 80 respondents are only the minimum number of respondents used. In other words, the respondents processed in this study could have more than 80 respondents. 

Vol. XVII No. 2 |Bulan J uli Tahun 2020

in this study the number of respondents used was 100 respondents.

Data collection was done using a Likert 5 scale questionnaire. To assess about new product attributes and intention to switch. Statements on the questionnaire were obtained from indicators on new product attributes and intention to switch. Questionnaire was distributed online. Questionnaire testing uses validity and reliability tests, to find out whether the questionnaire and the statements in the questionnaire can be used as a measurement tool.
Validity and reliability tests were conducted on the results of the answers of 30 respondents. Validity and reliability tests done by using the assistance of SPSS $22 \mathrm{fr}$ Windows. The results of the questionnaire were declared to have passed the reliability test but the three statements on the complexity were declared not to pass the validity test. So that the validity and reliability testing is done again by removing the complexity. The second validity and reliability tests result can be seen in Table 1 until Table 4.

TABLE 1. Compatibility Variable Statement Validity and Reliability Test Result

\begin{tabular}{clccc}
\hline No & \multicolumn{1}{c}{ Statement } & $\begin{array}{c}\text { Pearson } \\
\text { Correlation }\end{array}$ & Sig. & $\begin{array}{c}\text { Cronbach's } \\
\text { Alpha Value }\end{array}$ \\
\hline 1 & Use e-money according to my lifestyle. & 0,632 & 0,000 & 0,960 \\
\hline 2 & Use e-money according to my business. & 0,607 & 0,000 & 0,962 \\
\hline 3 & $\begin{array}{l}\text { Use e-money according to how I complete the } \\
\text { transaction. }\end{array}$ & 0,607 & 0,000 & 0,960 \\
\hline
\end{tabular}

TABLE 2. Convenience Variable Statement Validity and Reliability Test Result

\begin{tabular}{clccc}
\hline No & \multicolumn{1}{c}{ Statement } & $\begin{array}{c}\text { Pearson } \\
\text { Correlation }\end{array}$ & Sig. & $\begin{array}{c}\text { Cronbach's } \\
\text { Alpha Value }\end{array}$ \\
\hline 1 & e-money speed up in payments. & 0,818 & 0,000 & 0,958 \\
\hline 2 & e-money can save energy. & 0,774 & 0,000 & 0,958 \\
\hline 3 & e-money can save time. & 0,787 & 0,000 & 0,958 \\
\hline
\end{tabular}

TABLE 3. Perceived Content Variable Statement Validity and Reliability Test Result

\begin{tabular}{|c|c|c|c|c|}
\hline No & Statement & $\begin{array}{c}\text { Pearson } \\
\text { Correlation }\end{array}$ & Sig. & $\begin{array}{l}\text { Cronbach's } \\
\text { Alpha Value }\end{array}$ \\
\hline 1 & e-money speed up in payments. & 0,818 & 0,000 & 0,958 \\
\hline 2 & e-money can save energy. & 0,774 & 0,000 & 0,958 \\
\hline 3 & e-money can save time. & 0,787 & 0,000 & 0,958 \\
\hline 4 & $\begin{array}{l}\text { The content of the e-money application has been } \\
\text { updated with the latest developments. }\end{array}$ & 0,877 & 0,000 & 0,956 \\
\hline 5 & The contents of e-money are correct. & 0,861 & 0,000 & 0,956 \\
\hline
\end{tabular}

TABLE 4. Intention to Switch Variable Statement Validity and Reliability Test Result

\begin{tabular}{clccc}
\hline No & \multicolumn{1}{c}{ Statement } & $\begin{array}{c}\text { Pearson } \\
\text { Correlation }\end{array}$ & Sig. & $\begin{array}{c}\text { Cronbach's } \\
\text { Alpha Value }\end{array}$ \\
\hline 1 & The use of e-money is beneficial for transactions. & 0,783 & 0,000 & 0,958 \\
\hline 2 & It is likely that I will use e-money for the future. & 0,899 & 0,000 & 0,956 \\
\hline 3 & $\begin{array}{l}\text { Based on experience, I would very likely use e- } \\
\text { money }\end{array}$ & 0,783 & 0,000 & 0,957 \\
\hline
\end{tabular}


TABLE 5. Multiple Linear Regression Model Analysis Result

\begin{tabular}{lcc}
\hline \multicolumn{1}{c}{ Model } & $\begin{array}{c}\text { Unstandardized Coefficients } \\
(\mathbf{B})\end{array}$ & Sig. \\
\hline Constant & 0,783 & 0,033 \\
\hline Compatibility & 0,899 & 0,000 \\
\hline Convenience & 0,783 & 0,666 \\
\hline Perceived Content & 0,282 & 0,000 \\
\hline
\end{tabular}

After distributing and collecting the questionnaires, the data were analysed using multiple linear regression model analysis, multicollinearity test, multiple determination coefficient tests, $\mathrm{F}$ test, and $\mathrm{t}$ test. Analysis of multiple linear regression models is used to determine the effect of independent variables on the dependent variable if it has more than one independent variable. By using multiple linear regression analysis the regression formula is obtained. The multiple linear regression formula is:

$Y=1,651+0,417 X_{1}+0,030 X_{2}+0,282 X_{3}$

$\mathrm{Y}:$ Intention to switch

$\mathrm{X}_{1}$ : Compatibility

$\mathrm{X}_{2}$ : Convenience

$\mathrm{X}_{3}$ : Perceived Content

Multicollinearity test is used to see whether there are similarities between each dependent variable. $F$ test is used to see the extent to which the research model can be used to measure the dependent variable. $\mathrm{T}$ test is used to see the effect of each independent variable on the dependent variable. Multiple determination coefficient tests is used to find out the size of the contribution of the influence of variables.

\section{Research Model and Hypotheses}

Figure 2 shows the research model that have 3 independent variable. In analysis model framework shows that the new product attributes has 4 variables, but in validity test the complexity variable is not to past validity test. Therefore complexity variable must be eliminated in this research. So the research model in this research is like in Figure 2.

According to the research model in Figure 2 and multiple linear regression analysis, the research hypotheses in this research are:

$\mathrm{H}_{1}$ : Compatibility will have positive effect on intention to switch

$\mathrm{H}_{2}$ : Convenience will have positive effect on intention to switch

$\mathrm{H}_{3}$ : Perceived Content will have positive effect on intention to switch

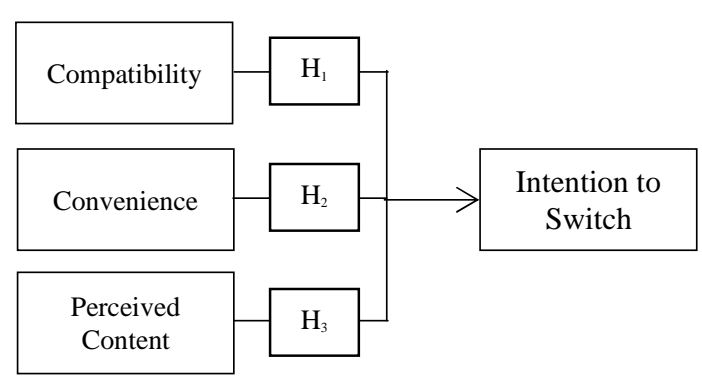

Figure 2. Research Model

\section{RESEARCH AND DISCUSSION RESULT}

The questionnaire was distributed is 100 respondents, but there were 14 respondents who did not match the sample characteristics. So there were 16 questionnaires distributed again and still have 2 respondents were did not match with sample characteristics of the sample. From the multiple linear regression analysis that have been done, the results obtained are the three independent variables (compatibility, 

Vol. XVII No. 2 |Bulan J uli Tahun 2020

convenience, and perceived content) have a positive effect to intention to switch. From the multicollinearity test, it was found that there were no similarities between the independent variables.

From the results of the multiple determination coefficient test results obtained that the three independent variables used have represented a number of $68.2 \%$ of the change in the value of the dependent variable influenced by the three variables studied, while the remaining $31.8 \%$ is influenced by other variables not included in the analysis model. The results of the $\mathrm{F}$ test show that research model can be used to measure the dependent variable. The results of the $t$ test show that compatibility variable and perceived content have an influence on intention to switch, but convenience variable have no an influence on intention to switch.

As shown in the results of testing the research hypotheses, there were compatibility and perceived content that have a significant impact toward intention to switch, and convenience is has no significant impact on intention to switch. The compatibility variable has an impact toward intention to switch. These results are matching with (Liander et al. 2016). Consumer will switch to e-money if they feel that e-money meet their need. e-money in the form of applications or cards are can be used in many ways. It can be used for transportation, buying food, buying what consumer want, and others. In addition, transactions using emoney are today's lifestyle. This can encourage consumers to use e-money.

Perceived content has a significant impact toward intention to switch. It is different with (Liander et al. 2016), in their research told that perceived content has no significant impact toward intention to switch because consumers are able to understand the content from e-book really well. But in emoney with the respondent are millennials, millennials consumer is understand technology very well. Millennials consumers already have a smartphone and are familiar with applications and software so they can easily operate it. Millennials also like the like the look of an attractive display in application. That is why perceived content has an influence on intention to switch.

Convenience variable has no significant impact on intention to switch, but in (Liander et al. 2016) say that convenience has a significant impact toward intention to switch. In (Liander et al. 2016), consumers feel that e-book is convenience to be used. This difference arises because millennial consumers still feel that transactions that use conventional money are still mostly done. In addition, there are still many outlets, traders, and sellers who do not yet provide electronic payments as mandatory payments so that payments with conventional money are still an option for consumers.

\section{CONCLUSSION}

Technological

developments, especially in finance, move quite rapidly. This is supported by infrastructure that can help technology to get closer to consumers. Many financial activities have used technology, ranging from ATMs, automatic deposit machines, telephone number accounts bank, to e-money. Coupled with millennial generation who are very knowledgeable about technology and can operate technology very well. It happened because millennial generation was born since smartphone, tablet and internet were already available so they could easily understand technology.

This research has been conducted but with more variables and different objects. Previous research using e-books as research objects. There are several different results between this research with previous research, because of the different objects studied. The results in this study indicate that millennial 

Vol. XVII No. 2 |Bulan J uli Tahun 2020

generation considers that the use of e-money is in line with current lifestyles. They can use e-money for their daily activities. Complete and interesting content in e-money applications also has an impact on millennial generation to use e-money. Because millennials like things that are sophisticated or related to technology. They are very active in cyberspace, they will always update new applications or new software that is being viral.

But in terms of convenience, millennials in Indonesia still feel doubt that emoney can facilitate their transactions. This happens because most Indonesian millennials are only a few who have worked so many still don't have a fixed income. Not having a fixed income will have an impact on their buying activities using e-money. They are still unable to replenish electronic money balances regularly. This will reduce on their transaction activities. This only happens in millennials in Indonesia, especially in the Province of East Java. Because the subjects in this study were e-money users in the Province of East Java.

Implications for the Business

With the development of e-money will provide changes in terms of payment. Conventional money circulation will slowly diminish and disappear. Moreover, Indonesia launched the cashless society movement. There have been many transactions that use emoney. Payment of all existing toll roads in Indonesia is done without cash. Gasoline purchases will also be planned using cashless. Almost all shops and parking lots in Indonesia already provide payment using emoney even accompanied by discounts or cash back.

For sellers in the future, small store until huge store must provide payment by emoney. Because e-money has become part of today's consumer lifestyle, not only millennial but all generations will use emoney in the future. Apart from lifestyle it is also due to state regulations that require payment by e-money or cashless. Besides emoney can provide convenience in transactions, e-money also has weaknesses in terms of information security and cyber crime. But if using e-money properly can reduce the impact of theft of personal data and cyber crime.

Limitation and Further Research

Although this research is in accordance with the objectives to be achieved, there are some problems and limitations, but this does not mean the results cannot be utilized or do not have a significant effect. Limits and problems are as follows:

First, the respondents in this study are only millennials so that they do not describe the overall behavior of those who have used e-money. Second, the variables used are still few because there is still little research on the interest in using e-money. In Indonesia emoney is still in its early stages, although many sellers have received e-money payments, but not all cities have implemented it.

Further research can add other variables or other methods so that it can provide more complete and varied results. Can also do research that examines differences in consumer behavior in the use of e-money in other cities, or differences between ethnicities, or between religions, and so on.

\section{BIBLIOGRAPHY}

Adiyanti, Arsita Ika. 2015. "Pengaruh Pendapatan, Manfaat, Kemudahan Penggunaan, Daya Tarik Promosi, Dan Kepercayaan Terhadap Minat Menggunakan Layanan E-Money (Studi Kasus : Mahasiswa Universitas Brawijaya)." 13.

Bansal, H. S. 2005. "Migrating to New Service Providers: Toward a Unifying Framework of Consumers' Switching Behaviors." Journal of 
BALANCE : Economic, Business, Management, and Accounting J ournal Vol. XVII No. 2 |Bulan J uli Tahun 2020

the Academy of Marketing Science 33(1):96-115.

Hair, Joseph F., ed. 2010. Multivariate Data Analysis: A Global Perspective. 7. ed., global ed. Upper Saddle River, NJ: Pearson.

Jabeen, Samrena, Abu Bakar Abdul Hamid, and Saif Ur Rehman. 2015. "Switching Intentions: A Case of Saudi Arabian Hypermarkets." 5:8.

Liander, Kevin, Silvia Margaretha, and Dudy Anandya 2016. "Consumers' Intention To Switch From Printed Book To E-Book In Surabaya." Journal of Management and Business 15(1).

Virtual Community." Behaviour \& Information Technology 28(5):421-31.

Rogers, Everett M. 1995. Diffusion of Innovations. 4th ed. New York: Free Press.

Schiffman, Leon G., and Leslie Lazar Kanuk. 2010. Consumer Behavior. 10. ed., global ed. Boston: Pearson/Prentice Hall. 